\title{
Invertebrates Diversity of Merta Segara and Nyangnyang Beach: Comparison Study of Two Beaches with Different Characteristics.
}

\author{
Buya Azmedia Istiqlal ${ }^{1 *}$, I Wayan Kasa ${ }^{2}$, Deny Suhernawan Yusup ${ }^{2}$ \\ ${ }^{1}$ Student of Magister Program on Department of Biology Udayana University \\ ${ }^{2}$ Lectures on Department of Biology Udayana Univeristy \\ Correspondence author: buyaazmedia@gmail.com
}

\begin{abstract}
The diversity of intertidal invertebrates in Bali was believed to be affected by human activities, due to high rate of development in tourism industry. In order to reveal the real natural invertebrate diversity, it is necessary to investigate it at a kind of untouched beach of Bali. This study was perform by comparing invertebrate diversity (species richness, density, community structure) and human activity (Type, frequency) in Merta Segara Beach, as the beach with frequent human activities, and Nyangnyang Beach, as the beach with little human activities. Invertebrates sample were taken within intertidal zone using line transect-quadrate during low tide. Human activities were observed in the afternoon from March to April 2016. The result showed a significant different in density and community structure between both Merta Segara and Nyangnyang beach as the consequences of different substrate type of both beaches. Walking on substrate or trampling was believed to be the most influencing activity for invertebrate diversity, especially for Merta Segara Beach. Next, a thorough study must be performed to conclusively tie the human activity to the alteration of invertebrate diversity in a coastal area. The high diversity, density and abundance of intertidal invertebrate of Nyangnyang Beach has literally shown that how diverse the biodiversity could be if the beach were protected from overexploited by tourism visitation and activity.
\end{abstract}

Keywords: Invertebrates diversity, human activity, Merta Segara Beach, Nyangnyang Beach

\section{INTRODUCTION}

Intertidal zone is located between the limit of lowest tide and highest tide, characterized by dynamic fluctuating physical circumstances [1]. This zone, even if it is sometimes very narrow, has many forms of marine life which can be observed with relative ease [2]. Ecological diversity in this zone can be very high with many species from many classes and genera present [3]. Thus, this zone has become a popular place to conduct study about marine community, in related to their natural habitat [4] [5] [6] or anthropogenic factors [7] [8] [9]. The zones also very important due to natural productivity provided for local people, and the beautiful landscape often attract many visitors, allowing the formation of recreational and tourism economics [10].

As human population has increased, the number of visitor to beach increase and their activities in the intertidal zone become to be more diverse [11]. These activities can have negative impact to natural community of marine organism. Most of stressor on intertidal zone are associated with human activity such as recreation, cleaning or grooming, nourishment, pollution, exploitation, biological invasion, coastal development and enginering, and climate change [12]. However, collection and trampling activity by local people and the present of artifcial structure at intertidal zone are believed to give a direct impact to intertidal organism, that is reducing the abundances and biodiversity [13] [8] [14]. Consequently, these kind of stressors have become important focus on intertidal ecological research.

Bali is wellknown as tourist destination where the beaches like Kuta, Legian, and Sanur are the most favourite place to be visited. As the large amount of tourist visit the beaches, the coastal area of Bali is recognised as thratened in term of environmental and biodiversity degradation. Recently, some study have been conducted to investigate the natural marine community of Bali coastal area [15] [16] [17] [18] [19] [20]. All the result of those studies mostly show the lower in species richness as well as abundace, compared to another studies conducted in another location such as in West Lesser Sunda [21], Sepanjang Beach [22], or in Mokupa Beach, Minahasa [23]. It can be argued that the intertidal invertebrates of Bali have been affected by tourism activity, since the coastal area of Bali have been developing since a long time ago. Consequently, in order to reveal the real narural intertidal diversity of Bali, it is necessary to conduct a research in a beach, without or with barely human activity on there.

Currently, there is only one study have been conducted in the remote untouched beach, which is called Nyangnyang Beach [24]. In fact, this beach have been not fully investigated and the information about marine community and beach characteristic are still poor, making this beach are perfectly suitable for conducting a research to reveal the real natural intertidal diversity of Bali. Thus, the study of marine intertidal community in the Nyangnyang Beach, as a representative of less exposed beach by human, has been conducted as well as the same study in Merta Segara Beach, as representative of more exposed beach by human. The main objective in this research was to compare the intertidal invertebrate community and their correlation with human activity between both Nyangnyang Beach and Merta Segara Beach.

\section{RESEARCH METHODS}




\section{Study Site}

The study was carried out at Merta Segara Beach and Nyangnyang Beach. Merta Segara Beach is located in Sanur district, $08^{\circ} 42^{\prime} 13.7 \mathrm{~S}$ dan $115^{\circ} 15^{\prime} 53.4$ E. Merta Segara Beach is typically a sandy beach with seagrass bed Recent study has shown that condition of the seagrass bed in Merta Segara Beach was the best among the beach of Sanur [25]. The beach is considered as water sport site and boats park [26]. The access to the beach is also very easy because the beach is located near the city of Denpasar. In the other hand, Nyangnyang Beach is located in Pecatu district, $08^{\circ} 50^{\prime} 21,0 \mathrm{~S}$ dan $115^{\circ} 05^{\prime} 35,5 \mathrm{E}$. The beach has a combination of sand, gravel and limestone subtratums [24]. The beach is relative quiet, without any facilty to support tourism activity yet. The access to the beach is also very complicated where no direct road lead to the coastline. It needs hundred downstair steps to get the beach.

\section{Protocols}

Sampling for invertebrates was conducted at February 11 and March 12, 2016 during low tide. At each location, five $100 \mathrm{~m}$ line-transects were laid from high to low tide, with interval $100 \mathrm{~m}$ between transects. The sample was taken using $1 \mathrm{~m}^{2}$ PVC quadrate placed along the linetransects. Each transects consisted of 10 quadrates. Thus, total quadrates sample were 50 quadrates in each location.
Field data samples were recorded in every quadrate including abundance of organisms, percentage of marine plants cover (seagrass and macroalgae) and the dominant substrate type.

Photographs of every macro invertebrates found in quadrate sample were taken in order to identify samples instead to preserve and transfer the samples to the laboratory. The common name is used to note the sample in the datasheet such as brittle star 1, hermit crab 2, cowry shell 3, etc. The percentage of seagrass and macroalga was determined using the standard photograph developed by Short et al [27]. The substratum was retrospectively divide into three category as sand, loose rock (mixed boulder, gravel, ruble), and limestone, modified from Kohn [28].

Observation of people at the study site was conducted between March to April 2016. The method to observed was following Murray et al [13]. Three weeks was taken for observation at each location. For one week, two days in the weekday and one day in the weekend was selected randomly as the sampling day for observation. Thus, the total day samples was 9 days for each location. The observation was done before sunset (around at $5 \mathrm{pm}$ ). The number of people visited the intertidal zone was counted every 10 minutes within 1 hour period to produce six 10 minutes samples. Their activity was noted as collecting or walking.

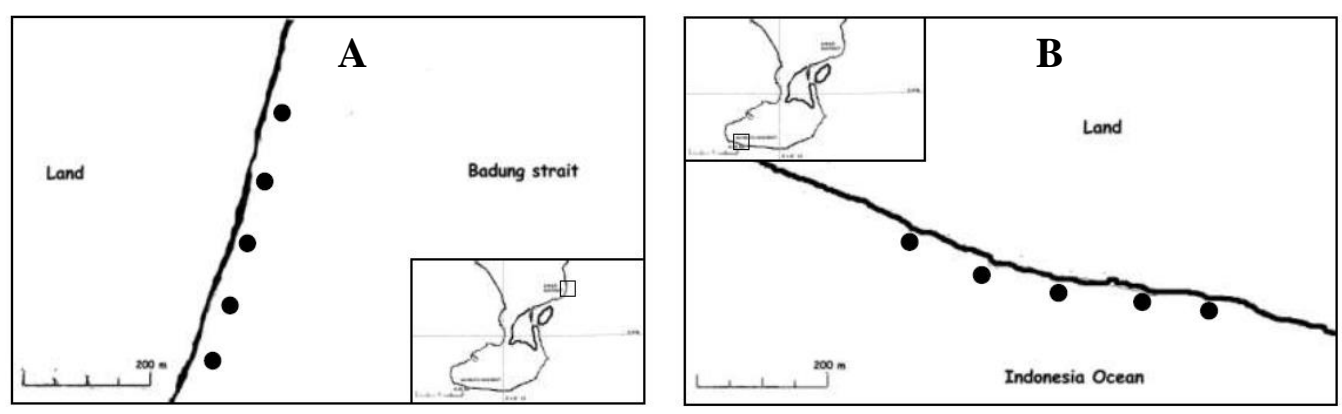

Fig 1. A. Merta Segara Beach, and B. Nyangnyang Beach. Dots indicate sampling points

\section{Data Presentation and Analysis}

All species recorded were listed based on taxonomy class. Additional information of their potential utilizations was also provided. The assemblages of invertebrate community between each location were measured using species richness, density and Diversity Index of ShannonWienner. The abundances in each substratum type and the average number of human visitor were compared using bar chart.

\section{RESULTS AND DISCUSSION}

\section{Result}

19 species belonging 9 classes were found at Nyangnyang Beach, while 10 species belonging 4 classes only were found at Merta Segara Beach. Scientific and common name and potential use by human were given on table below (Table 1 and 2). The species composition of both Merta Segara and Nyangnyang Beach were shown on Fig 2. In Merta Segara Beach, both of Nassarius spp and Strombus mutabilis have the same proportion (19\%). However, in Nyangyang Beach, Opiotrix spp had the most proportion (35\%), followed by Echinometra mathei (24\%) and hermit crabs (17\%), where the others represented by less than $10 \%$.

The measurement of some ecological statistic of Nyangnyang Beach and Merta Segara Beach were given on the table below (

TABLE 3). Based on the table, it could be seen that the total abundance and relative density of Nyangnyang beach was more than 10 times greater than Merta Segara Beach. However, the Diversity Index of Nyannyang Beach was lower than Merta Segara Beach

The distribution of invertebrates along the intertidal zone based on average density values were given on figure below (Fig 3). The bar on the graphic indicates the standard error. The result showed a very significant different of density's distribution between Merta Segara Beach and Nyangnyang Beach by pattern of the line in the graph. The distribution of percentage marine plant cover was given on the next figure (Fig 4). The graphics were shown with the mean value and standard deviation. The average marine plant covers of Merta Segara Beach tend to increase from high to low tide (up to $100 \mathrm{~m}$ ). However, the 
TABLE 1.

LIST OF INVERTEBRATES SPECIES FOUND ON NYANGNYANG BEACH

\begin{tabular}{|c|c|c|c|c|}
\hline Phylum & Class/Species & Common Name & Potential Uses & Reference \\
\hline \multirow[t]{2}{*}{ Cnidaria } & Anthozoa & & & [29] \\
\hline & o Anthopleura sp & Sea Anemone & - & \\
\hline \multirow[t]{2}{*}{ Annelida } & Polychaeta & & & {$[30]$} \\
\hline & - Eurythoe complanata & Fire worm & - & \\
\hline \multirow[t]{2}{*}{ Arthropoda } & Crustacea & & & [31] \\
\hline & $\begin{array}{ll}\circ & \text { Majidae } \\
\circ & \text { Paguroidea }\end{array}$ & $\begin{array}{l}\text { Spider Crab } \\
\text { Hermit Crab }\end{array}$ & & \\
\hline \multirow[t]{12}{*}{ Molusca } & Gastropoda & & & [32], [33] [34] \\
\hline & - Conus chaldeus & Cone Snail & Food, & \\
\hline & ○ C. coronatus & Cone Snail & Biomedical, & \\
\hline & ○ C.ebraeus & Cone Snail & Handy craft & \\
\hline & ○ C. lividus & Cone Snail & & \\
\hline & $\circ \quad$ C. miles & Cone Snail & & \\
\hline & - Cyprea moneta & Cowry Snail & Handy craft & Pers. Obs. \\
\hline & - Nerita spp & Nerites Snail & & \\
\hline & ○ Patella spp & Limpet & & \\
\hline & ○ Thais savignyi & Murex Snail & Food & \\
\hline & Polyplacophora & & & \\
\hline & - & Chiton & & {$[32]$} \\
\hline \multirow[t]{9}{*}{ Echinodermata } & Asteroidea & & & \\
\hline & - Linckia laevigata & Blue Sea Star & Ornament & [35] \\
\hline & Echinoidea & & & [36] \\
\hline & - Echinometra mathei & Rock-Boring & & \\
\hline & ○ Tripneustes gratilla & Urchin & & \\
\hline & & $\begin{array}{l}\text { Collector Sea } \\
\text { Urchin }\end{array}$ & Food & [37] \\
\hline & Holothuroidea & & & [38] \\
\hline & $\begin{array}{l}\text { ○ Holothuria sp } \\
\text { Ophiuroidea }\end{array}$ & Sea Cucumber & Food & [39] \\
\hline & - Ophiotrix sp & $\begin{array}{l}\text { Common Brittle } \\
\text { Star }\end{array}$ & & \\
\hline
\end{tabular}

TABLE 2.

LIST OF INVERTEBRATES SPECIES FOUND AT MERTA SEGARA BEACH

\begin{tabular}{|c|c|c|c|c|}
\hline Phylum & Class/Species & Common Name & Potential Uses & Reference \\
\hline \multirow[t]{4}{*}{ Echinodermata } & Asteroidea & & & \\
\hline & - Protoreaster nodosus & Common Sea Star & & {$[40]$} \\
\hline & Holothuroidea & & & [41] \\
\hline & - Synapta sp & Synapta & & \\
\hline \multirow[t]{10}{*}{ Molusca } & Bivalvia & & & [32], \\
\hline & ○ Pinna muricata & Penn Shell & Food & \\
\hline & Gastropoda & & & [33], \\
\hline & - Aplysia dactilomela & Sea Hares & & \\
\hline & Littorina $s p$ & Periwinkles & & \\
\hline & - Nassarius sp & Whelks & & \\
\hline & ○ Nerita $s p$ & Nerites Snail & & \\
\hline & Pleurobranchus forskalii & Forsklal's Sea Slug & & \\
\hline & Polinices sp & Moon Snail & & Pers. Obs. \\
\hline & ○ Strombus mutabilis & Variable stromb & Food & \\
\hline
\end{tabular}



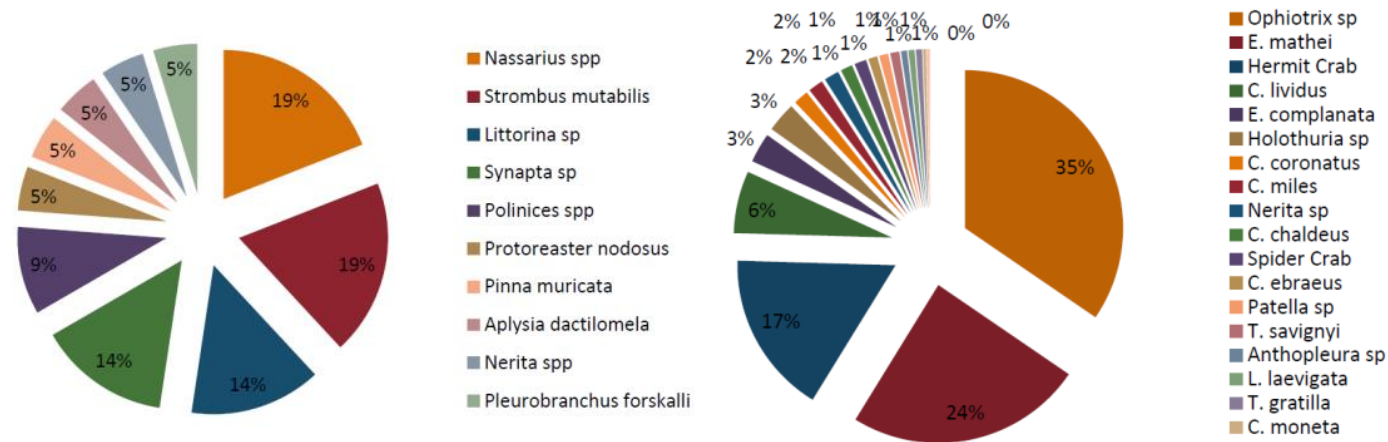

Fig 2. Species composition represented number of individual of (left) Merta Segara Beach and (right) Nyangnyang Beach

TABLE 3.

COMPARISON OF ECOLOGICALLY STATISTIC ANALYSIS OF BOTH NYANGNYANG AND MERTA SEGARA BEACH

\begin{tabular}{lcccccc}
\hline Location & $\begin{array}{c}\text { Species } \\
\text { Richness }\end{array}$ & $\begin{array}{c}\text { Total } \\
\text { Abundance }\end{array}$ & $\begin{array}{c}\text { Relative Density } \\
\left(\mathrm{ind} / \mathrm{m}^{2}\right)\end{array}$ & $\begin{array}{c}\text { Diversity } \\
\text { Index (H) }\end{array}$ & $\begin{array}{c}\text { Evenness } \\
\text { Index (E) }\end{array}$ & $\begin{array}{c}\text { Dominancy } \\
\text { Index (D) }\end{array}$ \\
\hline $\begin{array}{l}\text { Nyangnyang } \\
\text { Merta }\end{array}$ & 19 & 330 & 7.06 & 1.95 & 0.662 & 0.213 \\
Segara & $16.25^{*}$ & 21 & 0.42 & 2.13 & 0.927 & 0.133 \\
\hline
\end{tabular}
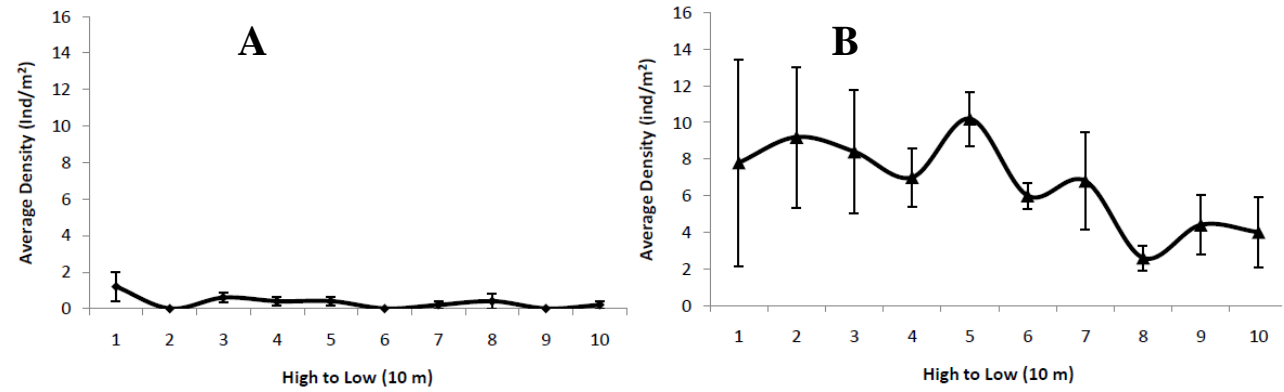

Fig 3. Distribution of average density of invertebrates along intertidal zone of A. Merta Segara Beach, and B. Nyangnyang Beach

A

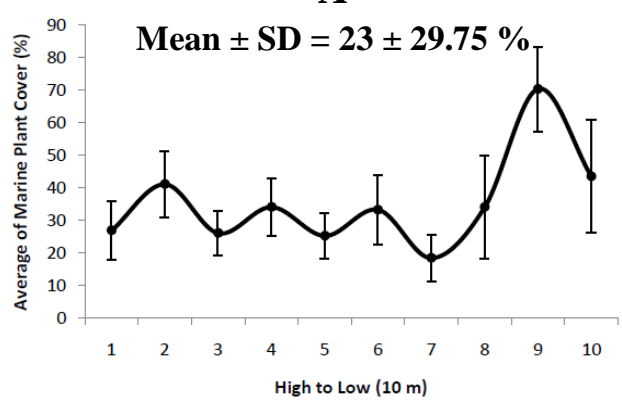

B

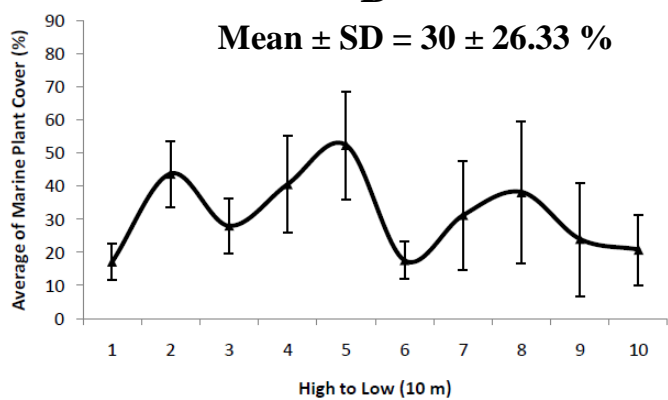

Fig 4. The distribution of percentage marine plant covers along intertidal zone of A. Merta Segara Beach, and B. Nyangnyang Beach

The frequency of substratum types observed together with the abundance of each substratum types were shown on the figure below (Fig 5). Sand substrate was dominance in Merta Segara Beach and no limestone substratum observed. Contrary, the limestone and loose rock were more frequent in Nyangnyang Beach. All organisms in Merta Segara Beach were found on sand substratum where most organisms were found on limestone in Nyangnyang Beach. 

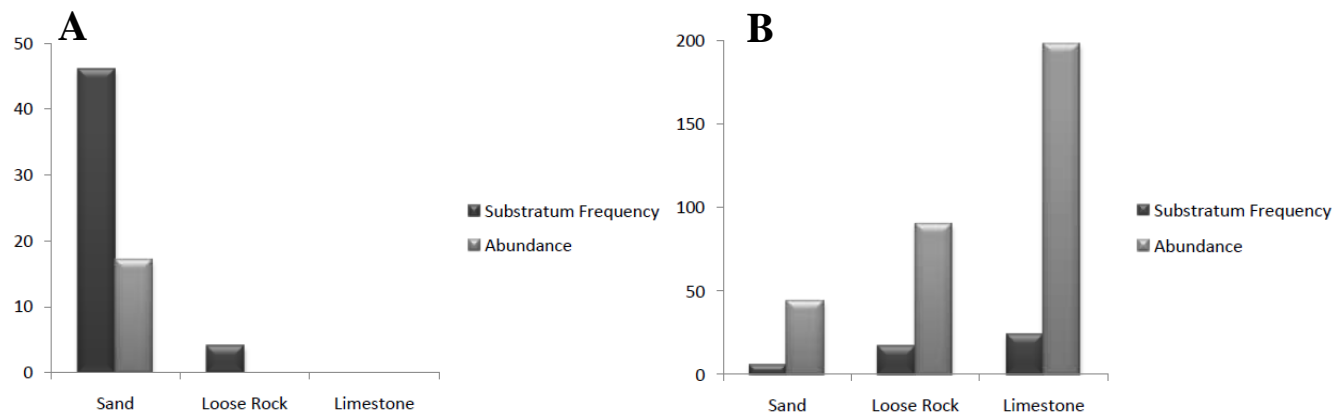

Fig 5. The frequency of substratum type observed with the abundance captured on each substratum type in A. Merta Segara Beach, and B. Nyangnyang Beach

Frequency of human activity in Merta Segara Beach were significantly greater than in Nyangnyang Beach, while the invertebrate density in Merta Segara Beach were much lower than in Nyangnyang Beach was (Error! Reference source not found.). Walking activity in Merta
Segara Beach was considerable and truly represents the number of daily visitor. Collecting activity reflect the number of fisherman in the beach. Furthermore the number of fisherman in Merta Segara Beach was quite higher than in

Beach.

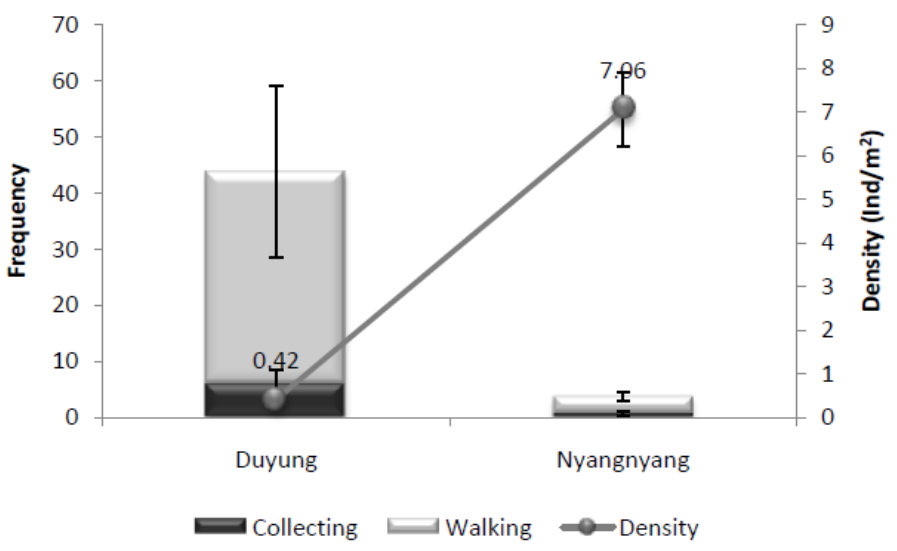

Fig 6. Comparison of frequency of human activity (walking and collecting) and relative invertebrate density between Merta Segara Beach and Nyangnyang Beach

\section{Discussions}

The invertebrates' community between Merta Segara Beach and Nyangnyang Beach were completely different. There was 19 species were found in Nyangnyang Beach while only 10 species were found in Merta Segara but only one species (Nerita $\mathrm{sp}$ ) were found in both locations. This result was clearly and naturally reflected the difference of marine community structure between sandy beach which represented by Merta Segara Beach and rocky beach which represented by Nyangnyang Beach [1].

The number species of Merta Segara Beach was very low compared by previous study at the same location [17] [19]. Perhaps, that was because of the different of number samples and area covered by the sample. In this reseach, only $100 \mathrm{~m}$ long the distance of intertidal area were covered as sample as the effort of equalizing the number sample between the two beaches - the length of intertidal zone of Nyangnyang Beach was approximately $100 \mathrm{~m}$. If the line-transect sample in Merta Segara Beach were streched, more species could be observed such as Conch Shell (Lambis chiragra), Tiger Cowry Shell (Cyprea tigris) and Collector Sea Urchin (Tripneustes gratilla). The Conch Shell and Tiger Cowry Shell were relative big, eyecathed and always be found in the previous study at Merta
Segara Beach. Moreover, The Collector Sea Urchin of Merta Segara Beach was abundant and famous as marine resource harvested by local fishery community [42]. The speciess richness value of Merta Segara Beach (16.25) was actually the expected species richness, which was taking notice to number of species that could present in the assemblage but not included in the samples [43].

The relative density in Nyangnyang Beach (7.06 ind $/ \mathrm{m}^{2}$ ) was more than 10 times higher than in Merta Segara Beach $\left(0.42 \mathrm{ind} / \mathrm{m}^{2}\right)$. However, more than $75 \%$ of total abundance of Nyangnyang Beach was presented by only three species (Ophiotrix spp $35 \%$, E. mathei $24 \%$ and group of Hermit Crabs $17 \%$, respectively), making the dominancy index was higher and diversity index was lower than Merta Segara Beach was. The dominancy by several species was typically characteristic of rocky shore. It was consistent with a previous study which showed the dominancy by several taxa in another rocky intertidal shore [6]. In the other hand, low density and evenly distributed of invertebrates species were commonly characteristic of sandy shore with seagrass bed [44].

As it has been said that the relative density in Nyangnyang Beach was greatly higher than Merta Segara Beach and giving the fact that frequency of human activity 
in Nyangnyang Beach was greatly lower than Merta Segara Beach was (Fig 6), the effect of human activity to the invertebrate diversity was still unclear. In this study, the collecting activity reflected for the present of fishermen. However, what did the fisherman harvest for were not observed at all. Nevertheless, the evidence of overexploid by collection activity such as the shif of the size frequency and the reduce spatfall [45] were not observed neither in this study, and if so, it need a past data of biological situation in that area to compare with current data obtained. Thus, in the future, it is necessary to investigate the biological impact of marine intertidal invertebrate in related to harvesting or collecting activity in a time series.

Where collecting activity was not given significant impact, the walking or trampling activity seemed to have more effect to invertebrate community, especially in Merta Segara Beach, which possessed both of low density of invertebrate (Fig 3) and low coverage of marine plant (Fig 4). The high frequency of trampling in Merta Segara Beach through toursm activity on the first $100 \mathrm{~m}$ of intertidal zone was suspected to give direct impact to marine plant. Recent study said that intensive trampling can reduce habitat complexity [46] leading to decrease of marine plant cover over time [7]. Consequently, this zone suffered of low primary productivity and missed the structural function from the loss vegetation. Therefore, it is make sense if there was found low invertebrate's density in the beach with high frequency of toursm activity like Merta Segara Beach.

In contras of Merta Segara Beach, Nyangnyang Beach has been experienced very little visitation leading to less trampling on the substrate. Therefore, the cover of marine plant in Nyangnyang Beach were higher than in Merta Segara Beach (Fig 4: 30\% vs 23\%). This level of coverage of marine plant seemed to be adequate for supporting the presence of invertebrate in Nyangnyang Beach. Recent study said that the greater coverage of algae occurred in a given area, the more species of macrofauna will be occurred [47]. This statement were considered relevant to our finding, that higher marine plant in Nyangnyang Beach, which mostly algae, were possessed more species and abundance of invertebrate than in Merta Segara Beach.

\section{CONCLUSION}

The diversity of intertidal invertebrate of Nyangnyang Beach as the "untouched" beach was finally revealed and totally showed that the level of relative density and abundance were a lot higher than in such a "high exploited" beach like Merta Segara Beach. Despite they were naturally different in term of beach type (sandy beach and rocky beach for Merta Segara and Nyangnyang, respectively), the human activity had a significant role to affect the invertebrate community especially in Merta Segara Beach, which the human activity that had been proven to give negative impact to intertidal invertebrate was the trampling.

\section{REFERENCES}

[1] J. W. Nybakken, Ekologi Laut Suatu Pendekatan Ekologi, Jakarta: PT Gramedia, 1988.
[2] J. W. Nybakken and S. K. Webster, "Life In The Ocean," in The Ocean, Scientific American, Inc., 1998, pp. 74-87.

[3] K. Tantikamton, N. Thanee, S. Jitpukdee and M. Potter, "Species Diversity And Ecological Characteristic Of Benthic Macroinvertebrates In The Intertidal Zone Of Satun Province, Thailand And The First Record Of Petersenapsis sp," Int'l Journal Of Advance In Agricultural \& Environmental Engg, vol. 2, no. 1, pp. 23-27, 2015.

[4] N. J. de Voogd, L. E. Becking and D. F. R. Cleary, "Sponge Community Compositon In The Derawan Island, NE Kalimantan, Indonesia," Marine Ecology Progress Series, vol. 396, pp. 169-180, 2009.

[5] K. L. White, S. M. Townsend, A. S. Reynolds and E. B. Barrington, "Intertidal Invertebrates In Scaterie Island: A Preliminary Species Inventory And Habitat Description," in Proceedings Of Nova Scotian Institute Of Science, 2010.

[6] A. M. P. Walag and M. O. P. Canencia, "Phsycochemical Parameters And Macrobenthic Invertebrates Of The Intertidal Zone Of Gusa, Cagayan de Oro City, Philippines," AES Bioflux, vol. 8, no. 1, pp. 7182, 2016.

[7] R. C. Presscot, "An Investigation Into The Impacts Of Recreational Activities Of Intertidal Assemblages At Westward Ho, Devon," Earth \& E-nvironment, vol. 2, pp. 211-252, 2006.

[8] M. N. Ferreira and S. Rosso, "Effect Of Human Trampling On Rocky Shore Fauna On The Sao Paulo Fauna, Southeasthern Brazil," Brazillian Journal Of Biology, vol. 69, no. 4, pp. 993-999, 2009.

[9] C. Bednar, "Human Impact On Rocky Intertidal Gastropods: Are Marine Protected Areas Effective?," San Jose State University, San Jose, 2015.

[10] J. Bower, "An Economocally Effisient Strategy For Coastal Defence And The Conservation of The Intertidal Zone," The Joint Marine Programme of The Wildlife Trusts and WWF, United Kingdom, 1999.

[11] A. Garcia and J. R. Smith, "Factor Influencing Human Visitation Of Southern California Rocky Intertidal Ecosystem," Ocean \& Coastal Management, vol. 73, pp. 44-53, 2013.

[12] O. Defeo, A. Maclachlan, D. S. Schoeman, T. A. Schlacher, J. Dugan, A. Jones, M. Lastra and F. Scpini, "Threats To Sandy Beach Ecosystem: A Review," Estuarine, Coastal And Shelf Science, vol. 81, pp. 1-12, 2009.

[13] S. N. Murray, T. G. Denis, J. S. Kido and J. R. Smith, "Human Visitation And The Frequency And Potential Effect Of Collecting On Rocky Intertidal Populations In Southern California Marine Reserve," CalCOFI, vol. 40, pp. 100-106, 1999.

[14] L. Airoldi and F. Bulleri, "Anthropogenic Disturbance Can Determine The Magnitude Of Opportunistic Species Responses On Marine Urban Infrastructure," PLOS ONE, vol. 6, no. 8, pp. 1-9, 2011.

[15] Linawati, "Komunitas Lamun dan Makro Epifauna Di Pantai Terora Nusa Dua dan Pantai Serangan 
Provinsi Bali," Universitas Udayana, Denpasar, 2005.

[16] N. I. Wiratmini, J. Wiryatno and A. A. G. R. Dalem, "Makrozoobenthos Pantai Pererenan (Kabupaten Badung): Jenis, Status, Dan Manfaatnya Bagi Masyarakat," Jurnal Bumi Lestari, vol. 8, no. 2, pp. 176-179, 2008.

[17] B. A. Istiqlal, D. S. Yusup and N. M. Suartini, "Distribusi Horizontal Moluska Di Kawasan Padang Lamun Pantai Merta Segara Sanur, Denpasar," Jurnal Biologi, vol. 17, no. 1, pp. 10-14, 2013.

[18] T. H. Laning, D. S. Yusup and J. Wiryatno, "Sebaran Bulu Babi (Echinoidea) Di Kawasan Padang Lamun Pantai Merta Segara, Sanur-Bali," Jurnal Biologi, vol. 18, no. 2, pp. 41-45, 2014.

[19] G. S. Indrawan, "Asosiasi Makrozoobentos Pada Padang Lamun Di Kawasan Perairan Sanur Bali," Universitas Udayana, Denpasar, 2014.

[20] K. Triwiyanto, "Keanekaragaman Moluska Di Pantai Serangan, Desa Serangan, Kecamatan Denpasar Selatan, Bali," Universitas Udayana, Denpasar, 2014.

[21] E. Yusron, "Keanekaragaman Jenis Ekhinodermata Di Perairan Teluk Kuta, Nusa Tenggara Barat," Makara, Sains, vol. 13, no. 1, pp. 45-49, 2009.

[22] A. Saputra, Marjono, D. P. Sari and Suwarno, "Keanekaragaman Makro-Invertebrata Di Pantai Sepanjang, Gunung Kidul, DI. Yogyakarta," in Seminar Nasional Konservasi Dan Pemanfaatan Sumber Daya Alam 2015, 2015.

[23] A. G. Kambey, U. N. W. J. Rembet and A. S. Wantase, "Komunitas Echinodermata Di Daerah Intertidal Perairan Pantai Mokupa Kecamatan Tomariri Kabupaten Minahasa," Jurnal Ilmiah Platax, vol. 3, no. 1, pp. 10-15, 2015.

[24] D. S. Yusup, "Rapid Assessment Of Invertebrates Community In Nyangnyang Beach," Cowow Foundation, Denpasar, 2012.

[25] H. Asy'ary, "Study Sebaran Spasial Tumbuhan Lamun Di Pantai Sekitar Denpasar," Universitas Udayana, Jimbaran, 2009.

[26] I. G. A. G. O. Gautama, "Evaluasi Pengembangan Wisata Bahari Di Pantai Sanur," Universitas Udayana, Denpasar, 2011.

[27] F. T. Short, L. J. McKenzie, R. G. Coles, K. P. Vidler and J. L. Gaeckle, SeagrassNet Manual For Scientific Monitoring Of Seagrass Habitat, Worldwide Edition ed., University Of New Hampshire Publication, 2006, p. 75 .

[28] J. A. Kohn, "Microhabitat Factor Affecting Abundance And Diversity Of Conus On Coral Reef," Oecologia, vol. 60, no. 3, pp. 293-301, 1983.

[29] D. Fautin, S. Tan and R. Tan, "Sea Anemones (Cnidaria: Actiniaria) of Singapore: Abundant and Well-Known Shallow-water Species," Raffles Bulletin of Zoology, vol. 22, pp. 121-143, 2009.

[30] K. Fauchald, The Polychaet Worms. Definitions And Keys To The Order, Families And Genera, Science Series 28 ed., Natural History Museum Of Los Angeles County, 1977, p. 188.

[31] FAO, FAO Species Identification Guide For Fisheries Purpose. The Living Marine Resources Of
The Western Central Pacific, Vols. Volume 2. Chepalopod, Crustacean, Holothurian, And Shark, K. E. Carpenter and V. H. Niem, Eds., Rome, 1998.

[32] B. Dharma, Siput Dan Kerang Indonesia Indonesian Shell, Jakarta: PT Sarana Graha, 1988.

[33] B. Dharma, Siput Dan Kerang Indonesia Indonesian Shell II, Jakarta: PT Sarana Graha, 1992.

[34] B. G. Livett, K. R. Gayler and Z. Khalil, "Drug From The Sea: Conopeptid As Potential Therapeutics," Current Medical Chemistry, vol. 11, no. 13, pp. 1715-1723, 2004

[35] M. Babtiste and I. Jakimovsy, "Linkia laevigata," Animal Diversity Web, 2011. [Online]. Available: https://animaldiversity.org/accounts/Linckia_laevigat a/. [Accessed 2711 2018].

[36] A. H. Clark, "Records Of Indo-Pacific Echinoderms," Pacific Science, vol. 8, pp. 243-263, 1954.

[37] A. Aziz, "Beberapa Catatan Tentang Perikanan Bulu Babi," Oseana, vol. 28, no. 2, pp. 65-75, 1993.

[38] R. Mulcrone, "Holothuroidea," 2005. [Online]. Available:

http://animaldiversity.org/accounts/Holothuroidea/. [Accessed 13 July 2016].

[39] P. Holland, "Ophiotrix fragilis," 2012. [Online]. Available:

http://animaldiversity.org/accounts/Ophiothrix_fragil is/. [Accessed 12 July 2016].

[40] R. Scheibling and A. Metaxas, "Abundance, Spatial Distribution, and Size Structure of the Sea Star Protoreaster nodosus in Palau, with Notes on Feeding and Reproduction," Bulleting of Marine Science, vol. 82, no. 2, pp. 221-235, 2008.

[41] J. B. S. Jontila, R. A. T. Balisco and J. A. Matillano, "The Sea Cucumbers (Holothuroidea) of Palawan, Philippines," AACL Bioflux, vol. 7, no. 3, pp. 194206, 2014.

[42] A. R. Yulianto, "Pemanfaatan Bulu Babi Secara Berkelanjutan Pada Kawasan Padang Lamun," Jakarta, 2012.

[43] R. K. Colwell, "Biodiversity: Concepts, Patterns, And Measurement," 2009. [Online]. Available: http://press.princeton.edu/chapters/s3_8879.pdf. [Accessed 0910 2015].

[44] A. S. Martinez, L. F. Mendes and T. S. Leite, "Spatial Distribution Of Epibenthic Molluscs On A Sandstone Reef In The Northeast Of Brazil," Brazillian Journal Of Biology, vol. 72, no. 2, pp. 287-298, 2012.

[45] L. J. Clarke, "Ecosystem Impacts of Intertidal Invertebrate Harvesting: from Benthic Habitats to Bird Predators," Bournemouth University, Bournemouth, 2018.

[46] L. C. Van De Werfhost and J. S. Pearse, "Trampling in the Rocky Intertidal of Central California: A Follow-up Study," Bulletin of Marine Science, vol. 81, no. 2, pp. 245-254, 2007.

[47] R. J. Best, A. L. Chaudoin, M. E. S. Bracken, M. H. Graham and J. J. Stachowicz, "Plant-animal Diversity Relationship in a Rocky Intertidal System Depend on Invertebrate Body Size and Algal Cover," Ecology, vol. 95, no. 5, pp. 1308-1322, 2014. 
